\title{
NIEPEWNOŚĆ INTERPRETACYJNA ZAPISÓW OCHRONY UBEZPIECZENIOWEJ KONSUMENTÓW UBEZPIECZEŃ NA ŻYCIE OFEROWANYCH DO KREDYTÓW MIESZKANIOWYCH NA PRZYKŁADZIE WYBRANYCH OFERT
}

\section{Katarzyna Nowak* \\ INTERPRETATION UNCERTAINTY OF CONSUMER LIFE INSURANCE OFFERED BY SELECTED BANKS}

\begin{abstract}
Bundled package of home loans and insurance are a natural phenomenon. Banks treat insurance as the primary security for the credit. For the consumer-borrower can help in financial difficulty. The purpose of insurance added to the loan is to reduce the risk of inability of borrowers to pay back their loans to banks and to ensure the safety of the insured or beneficiary of the insurance policy Therefore, insurance added to the loans should effectively protect borrowers. However, bundled package entails the risk of mismatching the insurance cover with the individual policyholder insurance needs. Consumer-borrower may not be aware of the scope of insurance protection, which results from the insurance contract and general insurance terms and conditions. Therefore, in order to properly understand the offer of insurance, it becomes necessary to familiarize the borrower-the consumer with the general insurance conditions. However, as research shows, there is a big problem on the insurance sector with unintelligible insurance policy. The purpose of the article/hypothesis: The aim of the article is to compare and assess the scope of insurance cover based on the provisions of the general conditions of life insurance added to home loans by the two largest banks in Poland.
\end{abstract}

\footnotetext{
*Szkoła Doktorska, Uniwersytet Ekonomiczny w Krakowie, e-mail: kasia.nowak88@wp.pl.
} 
Methodology: The article uses a comparative analysis of the scope of insurance cover on the based on provisions of the general conditions of insurance. The following categories have been selected from the general conditions of insurance: subject of insurance, definitions of events covered by the liability of the insurer, nature of benefits, amount of insurance and exclusions and limitations of liability.

Results of the research: the analysis of the scope of insurance cover at selected banks in the article shows that selected categories from the general terms and conditions of insurance limit the potential level of insurance cover. After reviewing the general terms and conditions of insurance, consumer-borrower is not sure whether he will get help from the insurer when he needs it.

Keywords: mortgage, life insurance, collateral of loans, bancassurance, consumer protection.

JEL Class: D18, G21, G22. 


\section{WSTĘP}

$\mathrm{Na}$ rynku bankowym rośnie liczba zadłużonych i średnia kwota zadłużenia. W 2020 r. banki udzieliły ponad 204 tys. kredytów mieszkaniowych na wartość około 60,7 mld zł. Na koniec 2020 r. średnia wartość udzielonego kredytu mieszkaniowego wyniosła 295563 zł. W porównaniu z 2019 r. przeciętna wartość wszystkich kredytów mieszkaniowych udzielonych w 2020r. wzrosła o 6,37\%, czyli o 17689 zł (Raport Amron-Sarfin..., 2021: 3).

W warunkach rosnącego zadłużenia rośnie potrzeba zapewnienia kredytobiorcom bezpieczeństwa, a tym samym ubezpieczenia. Zaciągnięcie kredytu podnosi ryzyko finansowe kredytobiorcy. W tym celu kredytobiorca-konsument ma do dyspozycji narzędzia ograniczające ryzyko, w tym ubezpieczenie.

Jednakże zawarcie umowy ubezpieczenia wiąże się z ryzykiem niedopasowania zakresu i poziomu ochrony ubezpieczeniowej do potrzeb konsumenta. Konsumenci mogą nie zdawać sobie sprawy z zakresu ochrony ubezpieczeniowej, jaki wynika z umowy. W związku z tym, w celu prawidłowego zrozumienia oferty ubezpieczenia, konieczne staje się zapoznanie przez kredytobiorcę-konsumenta z ogólnymi warunkami ubezpieczenia (dalej jako o.w.u.).

Jednak jak pokazują dotychczasowe badania, na rynku ubezpieczeniowym dostrzegalny jest duży problem związany z nieprzejrzystymi umowami ubezpieczenia oraz wzorcami umownymi. Przyczyną niskiej czytelności dokumentów uznaje się trudne słownictwo, a także skomplikowany język (Barczuk-Grędzińska, 2019: 73-85).Wyniki badania przeprowadzonego przez K. Barczuk-Grędzińską pokazały, że jednym z głównych czynników, który zniechęca konsumentów do zapoznawania się z treścią dokumentów ubezpieczeniowych jest niezrozumiały język. Ponadto prawie $88 \%$ respondentów odpowiedziało potwierdzająco, że spotkali się z przykładem umowy ubezpieczenia lub wzorca umownego, który został przez nich odebrany jako nieczytelny, niezrozumiały (Barczuk-Grędzińska, 2018: 184-187).

Natomiast badanie przeprowadzone przez J. Iwko wykazało, że większość ankietowanych (68\%) uważa, że postanowienia o.w.u. skonstruowane w sposób jednoznaczny i zrozumiały są najważniejszym elementem świadczącym o wysokiej jakości usług ubezpieczeniowych (Iwko, 2014: 286).

Również dane publikowane przez Recznika Finansowego odnośnie składanych skarg przez klientów ubezpieczycieli potwierdzają istnienie problemu. W 2020 r. do Rzecznika Finansowego wpłynęło 1619 wniosków dotyczących produktów ubezpieczeniowych, z czego aż 434 sprawy dotyczyły ubezpieczeń na życie wraz z ubezpieczeniami dodatkowymi i NNW (Sprawozdanie z działalności Rzecznika Finansowego w 2020 r..., 2021: 64-69). Skargi klientów dotyczyły zakresu ochrony ubezpieczeniowej oraz stosowanych przez ubezpieczycieli wy- 
łączeń odpowiedzialności. Istotne problemy w interpretacji zakresu ochrony ubezpieczeniowej według Rzecznika Finansowego powodują definicje pojęć, które w innych dziedzinach bardzo często są rozumiane szerzej, niż przyjmują to zakłady ubezpieczeń. Należy się zgodzić z M. Gawinem, że definiowanie przez zakłady ubezpieczeń zdarzeń objętych ochroną ubezpieczeniową jest istotnym czynnikiem decydującym o czytelności oferty (Gawin, 2018: 48-60).

Celem artykułu jest porównanie i ocena zakresu ochrony ubezpieczeniowej na podstawie zapisów ogólnych warunków ubezpieczenia w ubezpieczeniu na życie dodawanego do kredytów mieszkaniowych w Banku PKO BP i w Banku Pekao SA. Badanie to pozwoli na określenie formalnych ram ochrony ubezpieczeniowej w ubezpieczeniu na życie. Do przeprowadzenia analizy porównawczej zakresu ochrony ubezpieczeniowej z ogólnych warunków ubezpieczenia zostały wybrane następujące kategorie: przedmiot ubezpieczenia, definicje zdarzeń objętych odpowiedzialnością zakładu ubezpieczeń, charakter świadczeń, suma ubezpieczenia oraz wyłączenia i ograniczenia odpowiedzialności.

Artykuł został oparty na studiach literatury przedmiotu, analizie aktów prawnych i poglądów doktryny. Do analizy porównawczej zapisów ogólnych warunków ubezpieczenia wzięto pod uwagę ogólne warunki ubezpieczenia dostępne w ofercie wybranych banków w 2020 r. Postanowienia zawarte w o.w.u., które wymagały doprecyzowania były konsultowane z pracownikami tych banków.

\section{CHARAKTERYSTYKA UBEZPIECZENIA NA ŻYCIE ŁĄCZONEGO Z KREDYTEM MIESZKANIOWYM}

Banki dystrybuują ubezpieczenia w ramach współpracy z zakładami ubezpieczeń określanej terminem bancassurance. Termin ten nie ma definicji prawnej i został wykreowany przez praktykę gospodarczą. Banki bardzo często oferują ubezpieczenia w pakietach, w ramach sprzedaży łączonej ${ }^{1}$ - łącząc ich sprzedaż ze świadczeniem usług bankowych dla klienta: prowadzeniem konta, kredytem hipotecznym lub konsumpcyjnym (P. Nowak, 2018: 164-174).

W przypadku ubezpieczeń łączonych z kredytem mieszkaniowym istotne jest wskazanie pozycji i roli banku pomiędzy ubezpieczycielem a kredytobiorcą. Bank może wystąpić jako ubezpieczający w umowie ubezpieczenia grupowego lub jako agent ubezpieczeniowy oferując ubezpieczenia indywidualne. Możliwość kształtowania sytuacji prawnej przez ubezpieczonego w przypadku ubezpieczenia grupowego jest znacznie węższa $\mathrm{w}$ porównaniu $\mathrm{z}$ umową ubezpieczenia indywidualnego (Więcko-Tułowiecka, 2015: 42). Z tego względu, istotne dla konsumenta

${ }^{1}$ Definicja sprzedaży łączonej zawarta jest w art. 4 pkt. 18 ustawy o kredycie hipotecznym oraz o nadzorze nad pośrednikami kredytu hipotecznego i agentami, t.j. Dz.U. 2020, poz. 1027 ze zm. 
jako ubezpieczonego jest, czy zawiera umowę ubezpieczenia indywidualnego, czy grupowego.

Od 2015 r. zdecydowana większość banków przestała oferować ubezpieczenia grupowe. Obecnie na rynku bancassurance większość ubezpieczeń oferowana jest w charakterze ubezpieczeń indywidualnych, w których banki występują jako agenci ubezpieczeniowi. Przyczyny tak dużej zmiany na rynku należy upatrywać we wprowadzonych regulacjach prawnych (K. Nowak, 2020: 75-86), a w szczególności w Rekomendacji U z 2014 r. (Rekomendacja U dotyczaca dobrych praktyk $w$ zakresie bancassurance, 2014), (rekomendacja 7) oraz w ustawie $\mathrm{z}$ dnia 11 września 2015 r. o działalności ubezpieczeniowej i reasekuracyjnej (t.j. Dz.U. 2020, poz. 895 ze zm.), (dalej jako u.d.u.r.), które zakazały wynagradzania banków (jako ubezpieczających) w związku z oferowaniem możliwości skorzystania z ochrony ubezpieczeniowej lub czynnościami związanymi z wykonywaniem umowy ubezpieczenia (art. 18 ust. 1. u.d.u.r.). Powyższe stanowisko ustawodawcy zostało również podtrzymane w ustawie z dnia 15 grudnia 2017 r. o dystrybucji ubezpieczeń (t.j. Dz.U. 2019, poz. 1881 ze zm.), w której ubezpieczający nie jest pośrednikiem ubezpieczeniowym, a więc nie dystrybuuje on ubezpieczeń, w związku z tym za oferowanie możliwości skorzystania z ochrony ubezpieczeniowej oraz za czynności związane z wykonaniem umowy ubezpieczenia nie powinien otrzymywać wynagrodzenia.

Zakaz wynagradzania ubezpieczających spowodował, że część banków odeszła od grupowego modelu sprzedaży ubezpieczeń na rzecz sprzedaży agencyjnej. Banki zmieniły formę sprzedaży i zaczęły oferować klientom ubezpieczenia w ramach ubezpieczenia indywidualnego. Ponadto banki jako agenci ubezpieczeniowi muszą wywiązywać się m.in. z licznych obowiązków przedkontraktowych, które nakłada na nie ustawa o dystrybucji ubezpieczeń.

W związku z zaciągnięciem kredytu mieszkaniowego po stronie kredytobiorcy-konsumenta rośnie ryzyko utraty zdolności do wykonywania zobowiązań finansowych. Do czynników, na które narażony jest kredytobiorca i które przyczyniają się do powstania ryzyka zaprzestania spłaty kredytu można uznać następujące ryzyka: śmierci, utraty zdrowia oraz utraty dochodu. Dlatego kredytobiorcy korzystają z rozwiązań służących ograniczaniu tego ryzyka. Banki w ramach współpracy z zakładami ubezpieczeń oferują ubezpieczenia łączone z kredytem, które mają chronić kredytobiorców. Do grupy ubezpieczeń łączonych z kredytem należą: ubezpieczenie życia, ubezpieczenie zdrowia, ubezpieczenie dochodu, a także ubezpieczenie od niskiego wkładu własnego oraz ubezpieczenie nieruchomości od ognia i innych zdarzeń losowych.

Kredyty mieszkaniowe można zakwalifikować do kredytów długoterminowych. $Z$ tego też powodu jednym z ważniejszych czynników branych pod uwage przez bank jest ryzyko śmierci kredytobiorcy w czasie trwania umowy kredytu. Także kredytobiorca-konsument powinien brać pod uwagę ryzyko, że wraz z jego 
śmiercią bezpieczeństwo finansowe jego rodziny może ulec obniżeniu (Mrozowska i Wnęk, 2014: 30-46; Rejda i McNamara, 2018: 199-201).

Ubezpieczenie na życie w przypadku realizacji zdarzenia losowego tj. śmierci kredytobiorcy powinno chronić jego rodzinę (uposażonych) przed późniejszymi problemami związanymi ze spłatą kredytu i zapewnić osobom zależnym od ubezpieczonego określonego standardu życia po jego śmierci. Celem tego ubezpieczenia jest więc rekompensata uszczerbku finansowego, jaki może powstać w budżecie gospodarstwa domowego w wyniku śmierci danej osoby (ubezpieczonego) (Barembruch, 2018: 340). Ponadto ubezpieczenia na życie mogą stanowić zabezpieczenie dla samego kredytobiorcy (ubezpieczonego) na wypadek nieszczęśliwych zdarzeń, takich jak np. niezdolność do pracy, choroba, które powodują zmniejszenie dochodów lub zwiększenie wydatków (Stęplewska, 2016: 63).

Ubezpieczenie na życie może stać się wymagane przez bank w przypadku zaistnienia określonych okoliczności, np. po przekroczeniu określonego wieku kredytobiorcy, gdy kredytobiorca jest tylko jedna osoba albo gdy udział jednego kredytobiorcy w całkowitych dochodach wszystkich współkredytobiorców jest zbyt wysoki (P. Nowak, 2020: 325-340).

W ubezpieczeniu na życie ze względu na fakt, że należy ono do ubezpieczeń osobowych, nie da się oszacować wartości ludzkiego życia, co z kolei przekłada się na niemożność ustalenia wysokości szkody w przypadku realizacji danego ryzyka. Dlatego w momencie powstania szkody osobowej ubezpieczyciel wypłaci świadczenie, którego wartość może wynikać z umowy ubezpieczenia i będzie zależeć od sumy ubezpieczenia (Kawiński, 2017: 169). W ubezpieczeniu tym wysokość sumy ubezpieczenia ustalona jest umownie i stanowi ona kwotę, którą ubezpieczyciel musi wypłacić w razie zaistnienia wypadku ubezpieczeniowego.

Omawiane ubezpieczenie na życie, stanowiące zabezpieczenie spłaty kredytu jest ubezpieczeniem terminowym (Dorfman, 2013: 261), ponieważ ochrona ubezpieczeniowa obowiązuje tylko w okresie trwania umowy kredytu i wygasa wraz $\mathrm{z}$ tą umową. Wypłata świadczenia przez ubezpieczyciela nastąpi tylko wtedy, gdy spełnione zostaną pewne warunki, tj. umowa ubezpieczenia była w mocy oraz jeżeli zdarzenie zrealizuje się w trakcie trwania kredytu i nie będzie podlegało wyłączeniu odpowiedzialności ubezpieczyciela.

W umowie ubezpieczenia na życie powiązanego z kredytem suma ubezpieczenia określana jest kwotowo i maleje wraz ze spłacanianym zobowiązaniem (suma ubezpieczenia równa się kwocie kredytu pozostałego do spłaty). Oznacza to, że składka ubezpieczeniowa płacona jest z góry, a suma ubezpieczenia będzie odpowiadać wysokości kredytu pozostałego do spłaty (Śliwiński, 2016: 302).

Zawarcie umowy ubezpieczenia na życie powinno być poprzedzone procesem oceny ryzyka ubezpieczeniowego tzw. underwritting. Do oceny ryzyka ubez- 
pieczeniowego, ubezpieczyciel może wymagać od ubezpieczonego przedstawienia dokumentacji medycznej odnośnie jego stanu zdrowia lub przeprowadzenia na jego zlecenie badań medycznych. Na podstawie zebranych informacji ubezpieczyciel dokonuje analizy ryzyka i dopiero na jej podstawie podejmuje stosowną decyzję: o zawarciu umowy, odmowie zawarcia umowy lub o zawarciu umowy na odmiennych warunkach (Dąbrowska, 2018: 283).

Bank zabezpiecza się także wymagając, aby ubezpieczający w umowie ubezpieczenia na życie wskazał bank jako podmiot uposażony. W takiej sytuacji w razie śmierci ubezpieczonego świadczenie z ubezpieczenia na życie będzie wypłacane bankowi, który przeznaczy je na spłatę części lub całości zobowiązania.

$\mathrm{W}$ indywidualnym ubezpieczeniu na życie zgodnie $\mathrm{z}$ art. $831 \S 1$ Kodeksu cywilnego (Ustawa z dnia 23 kwietnia 1964 r..., t.j. Dz.U. 2020, poz. 1740 ze zm.) prawo do wskazania osoby uposażonej, której przysługuje roszczenie o zapłatę kwoty pieniężnej w razie śmierci ubezpieczonego przysługuje ubezpieczającemu (konsumentowi). Ponadto ubezpieczający ma prawo do zmiany i odwołania uposażonego w dowolnym momencie trwania umowy ubezpieczenia. $Z$ tego względu po stronie banku powstaje niepewność co do skuteczności tego zabezpieczenia kredytu. Zabezpieczenie staje się mniej pewne, ponieważ kredytobiorca może bez żadnych ograniczeń wksazać, zmienić i odwołać uposażonego (Orlicki, 2013: 256-264). Dlatego bank, który nie ma możliwości kształtowania stosunku prawnego w umowie ubezpieczenia indywidualnego, wykorzystuje umowy zawierane z ubezpieczającym, w których konsument (ubezpiecający) wyznacza bank jako uposażonego oraz zobowiązuje się nie dokonywać zmiany uposażonego przez cały okres trwania umowy kredytu mieszkaniowego (Mrozowska i Wnęk, 2014: 30-46). Takie zobowiązanie wiąże jednak tylko strony tej umowy, czyli bank i kredytobiorcę, a więc nie ma przeszkód, aby kredytobiorca (ubezpiecający) dokonał zmiany osoby uposażonego, co będzie skuteczne wobec ubezpieczyciela (Szydłowska, 2018: 51-68). Ponadto, ubezpieczający ma prawo zmienić osobę uposażoną i tego uprawnienia nie może zostać pozbawiony (Heropolitańska, 2018: 467). Bank może jedynie zwrócić się do ubezpieczyciela $\mathrm{z}$ wnioskiem o informowanie banku w przypadku ewentualnej zmiany uposażonego przez ubezpieczającego oraz określić $\mathrm{w}$ umowie $\mathrm{z}$ dłużnikiem zakres uprawnień przysługujących wierzycielowi w takiej sytuacji.

Odmiennie przedstawia się sytuacja w przypadku grupowych ubezpieczeń na życie, w których bank jest ubezpieczającym i to jemu zgodnie $\mathrm{z}$ art. $831 \S 1^{1}$ k.c. przysługuje prawo do wskazania, odwołania lub zmiany uposażonego po wcześniejszej zgodzie ubezpieczonego, chyba że postanowienia ogólnych warunków umowy lub umowa ubezpieczenia wskazują inaczej. W grupowym ubezpieczeniu na życie nie będzie więc potrzebna dodatkowa umowa zawarta pomiędzy bankiem a ubezpieczającym, ponieważ wskazanie banku jako uposażonego następuje na postawie zgody kredytobiorcy. 


\section{ZAKRES OCHRONY W UBEZPIECZENICH NA ŻYCIE W BANKU PKO BP I BANKU PEKAO SA}

Podjęty problem badawczy dotyczy oceny zakresu ochrony ubezpieczeniowej w ubezpieczeniach na życie dodawanych do kredytów mieszkaniowych. W przeprowadzonym badaniu ocenie zakresu ochrony ubezpieczeniowej podlega wyłącznie jej formalny zakres wynikający z zapisów o.w.u.

W artykule została przeprowadzona analiza porównawcza zakresu ochrony ubezpieczeniowej na podstawie zapisów ogólnych warunków ubezpieczenia dostępnych w ofercie wybranych banków w 2020 r. Analizowane ogólne warunki ubezpieczenia zostały przekazane wraz z ofertą kredytu mieszkaniowego od pracowników badanych banków.

Dobór banków został dokonany na podstawie danych opublikowanych przez miesięcznik „Bank”, który w ramach corocznie sporządzanego rankingu największych banków w Polsce przedstawia podranking banków obejmujący aktywność na rynku kredytowym. W rankingu za 2018 r. pierwsze trzy miejsca, w kategorii „wartości portfela kredytów” zajęły: PKO BP, Santander oraz Bank Pekao SA (XXIV Ranking Banków, 2019: 21). Zdecydowanym liderem w działalności kredytowej w 2018 r. był PKO BP, którego portfel kredytowy był ponad 50\% większy w stosunku do Santander Banku, a także Banku Pekao SA. Udział w rynku trzech największych liderów w działalności kredytowej wynisół prawie 50\%.

Również w rankingu gazety „Newsweek” w kategorii „bankowość hipoteczna" pierwsze trzy miejsca zajęły: Bank Pekao SA, PKO BP oraz Alior (Ranking przyjazny bank „Newsweeka”, 2019: 64).

$\mathrm{W}$ ten sposób analiza zapisów o.w.u. została przeprowadzona na podstawie ubezpieczeń oferowanych do kredytów mieszkaniowych dla osób zawierających umowę kredytu przez dwa największe banki w Polsce: PKO Bank Polski SA (dalej PKO BP) oraz Banku Pekao SA (dalej Bank Pekao). Badania przeprowadzono na początku $2020 \mathrm{r}$.

W analizie zakresu ochrony został uwzględniony: przedmiot ubezpieczenia, definicje zdarzeń objętych odpowiedzialnością zakładu ubezpieczeń, charakter świadczeń, suma ubezpieczenia oraz wyłączenia i ograniczenia odpowiedzialności. W przypadku wątpliwości odnośnie postanowień były one wyjaśniane w trakcie rozmów z pracownikami tych banków.

Zarówno PKO BP jak i Bank Pekao występują w dystrybucji ubezpieczeń dodawanych do kredytów mieszkaniowych w charakterze agentów ubezpieczeniowych $\mathrm{i}$ oferują klientom nabycie ubezpieczenia w ramach zawarcia umowy ubezpieczenia (ubezpieczenie indywidulane). Dla ubezpieczeń na życie, PKO BP jest dystrybutorem ubezpieczeń PKO Życie Towarzystwo Ubezpieczeń SA, a Bank Pekao SA dystrybuuje ubezpieczenia na wypadek utraty dochodu oraz 
zgonu w następstwie nieszczęśliwego wypadku Sopockiego Towarzystwa Ubezpieczeń ERGO Hestia SA.

PKO BP oferuje ubezpieczenie na życie w zakresie: 1) zgonu ubezpieczonego i 2) wystąpienia u ubezpieczonego trwałej i całkowitej niezdolności do pracy i samodzielnej egzystencji będącej następstwem nieszczęśliwego wypadku. Zapis drugiego zdarzenia objętego ochroną wskazuje, że należy te dwie sytuacje traktować łącznie jako warunek ochrony ubezpieczeniowej. Za nieszczęśliwy wypadek przyjmuje się ,zdarzenie nagłe, wywołane działającą nagle i niezależnie od woli oraz stanu zdrowia Ubezpieczonego, przyczyną zewnętrzną z wyłączeniem działania czynników biologicznych (drobnoustrojów chorobotwórczych i pasożytów), będące bezpośrednią i wyłączną przyczyną wystąpienia zdarzenia objętego zakresem ubezpieczenia". Nieszczęśliwy wypadek musi być niezależny od stanu zdrowia ubezpieczającego, co oznacza, że w wypadkach wątpliwych ubezpieczyciel może starać się udowodnić, że zgon nastąpił w wyniku choroby, co zwalniałoby go z odpowiedzialności. Ubezpieczyciel potencjalnie może również stać na stanowisku, iż nie doszło do zdarzenia nagłego, wywołanego przyczyną zewnętrzną.

Trwała i całkowita niezdolność do pracy i samodzielnej egzystencji rozumiana jest jako „trwała i całkowita niezdolność do pracy i samodzielnej egzystencji orzeczona przez uprawniony organ do orzekania w sprawie oceny zdolności do pracy (...) niezdolność do samodzielnej egzystencji oznacza naruszenie sprawności organizmu w stopniu, który powoduje konieczność stałej lub długotrwałej opieki i pomocy innej osoby w celu zaspokajania podstawowych potrzeb życiowych"2.

Pozytywny zakres ochrony obciążony jest licznymi wyłączeniami i ograniczeniami odpowiedzialności, co prowadzi do zawężenia ochrony ubezpieczeniowej. Wyłączenia można podzielić na dwie grupy: wyłączenia o charakterze ogólnym, stosowane we wszystkich umowach oraz wyłączenia szczególne. W PKO BP zakres ochrony był ograniczony tylko przez wyłączenia o charakterze ogólnym, które uchylają odpowiedzialność zakładu ubezpieczeń, która jest następstwem $^{3}$ :

1) wojny, działań zbrojnych, stanu wojennego, działania energii jądrowej;

2) czynnego udziału ubezpieczonego w zamieszkach lub w aktach terroryzmu bądź innych aktach przemocy;

3) próby samobójczej ubezpieczonego w okresie pierwszych dwunastu miesięcy od rozpoczęcia okresu odpowiedzialności;

2 § 2. ust. 23 Ogólne warunki ubezpieczenia na życie dla klientów PKO BP i PKO Banku Hipotecznego SA, którzy zawarli umowy kredytu lub pożyczki zabezpieczone hipoteką, PKO Życie Towarzystwo Ubezpieczeń SA, UI/OWU/138/04-2017/A, s. 2.

${ }^{3} \S 5$. ust. 1 Ogólne warunki ubezpieczenia na życie dla klientów PKO BP i PKO Banku Hipotecznego SA, którzy zawarli umowy kredytu lub pożyczki zabezpieczone hipoteką, PKO Życie Towarzystwo Ubezpieczeń SA, UI/OWU/138/04-2017/A, s. 3. 
4) usiłowania lub dokonania przestępstwa przez ubezpieczonego;

5) pozostawania pod wpływem alkoholu przez ubezpieczonego, zażycia środków odurzających (w tym leków) lub środków psychotropowych, narkotyków, wyłączając przypadki, gdy ubezpieczony przyjmował te środki w ramach zaleconej przez lekarza terapii medycznej;

6) prowadzenia pojazdu mechanicznego lub innego pojazdu przez ubezpieczonego, jeżeli ubezpieczony nie posiadał ważnych uprawnień wymaganych przez prawo o ruchu drogowym, albo jeżeli ubezpieczony kierował tym pojazdem pozostając pod wpływem alkoholu, środków odurzających (w tym leków), środków psychotropowych lub narkotyków;

7) leczenia lub innych zabiegów o charakterze medycznym, którym dobrowolnie poddał się ubezpieczony, prowadzonymi poza kontrolą osób posiadających uprawnienia wymagane przepisami prawa;

8) uprawiania przez ubezpieczonego narciarstwa zjazdowego, snowboardingu lub saneczkarstwa poza wyznaczonymi trasami zjazdowymi, jazdy bobslejem, kolarstwa ekstremalnego, sportów walki, wspinaczki górskiej lub skałkowej wymagającej użycia specjalistycznego sprzętu, speleologii, skoków bungee, zorbingu, wyścigów, rajdów lub akrobacji motorowych lub motorowodnych, wyścigów konnych, górskich spływów wodnych, nurkowania (z wyłączeniem amatorskiego nurkowania), skoków do wody, żeglarstwa morskiego lub oceanicznego, paralotniarstwa, szybownictwa, baloniarstwa, lotniarstwa, motolotniarstwa, spadochroniarstwa, myślistwa oraz wypraw na bieguny i tereny lodowcowe lub śnieżne wymagających użycia sprzętu asekuracyjnego;

9) wypadku lotniczego, za wyjątkiem przypadków, gdy ubezpieczony był pasażerem bądź członkiem załogi samolotu licencjonowanych linii lotniczych.

Ponadto jeżeli ubezpieczony zatai znane sobie okoliczności, o które ubezpieczyciel pytał przed zawarciem umowy, to ubezpieczyciel nie ponosi odpowiedzialności za skutki tych okoliczności w ciągu 3 lat od zawarcia umowy ${ }^{4}$.

Poziom świadczeń jest identyczny w przypadku zajścia każdego ze zdarzeń. Określa go suma ubezpieczenia. Suma ubezpieczenia określa górną granicę do której zakład ubezpieczeń ponosi odpowiedzialność za szkodę w okresie ubezpieczenia. Obejmuje ona jedno zdarzenie lub wszystkie w okresie ubezpieczenia. Sumy ubezpieczenia ustalane są zazwyczaj w mechaniźmie do wyczerpania, co oznacza, że każda wypłata świadczenia przez ubezpieczyciela zmniejsza sumę ubezpieczenia.

Suma ubezpieczenia w pierwszym okresie ubezpieczenia jest równa kwocie kredytu (jeżeli kredytobiorca zawarł umowę ubezpieczenia nie później niż w dniu

${ }^{4} \S$ 5. ust. 3 Ogólne warunki ubezpieczenia na życie dla klientów PKO BP i PKO Banku Hipotecznego SA, którzy zawarli umowy kredytu lub pożyczki zabezpieczone hipoteką, PKO Życie Towarzystwo Ubezpieczeń SA, UI/OWU/138/04-2017/A, s. 3. 
wypłaty całkowitej kwoty kredytu) oraz wysokości salda zadłużenia na dzień zawarcia umowy ubezpieczenia (jeżeli do zawarcia umowy ubezpieczenia doszło po dniu wypłaty całkowitej kwoty kredytu), a po zakończeniu pierwszego okresu ubezpieczenia jest równa saldu zadłużenia z dnia poprzedzającego początek miesiąca ochrony, w którym nastąpiło zdarzenie ubezpieczeniowe.

Jeżeli jedna umowa kredytu zawierana jest przez kilka osób fizycznych jako kredytobiorców, ubezpieczyciel może objąć maksymalnie dwie z tych osób ubezpieczeniem.

W przypadku zgonu lub trwałej i całkowitej niezdolności do pracy i samodzielnej egzystencji będącej następstwem nieszczęśliwego wypadku wysokość świadczenia ubezpieczyciela jest równa ${ }^{5}$ :

1) w pierwszym okresie ubezpieczenia iloczynowi pierwotnego udziału procentowego i sumy ubezpieczenia,

2) po zakończeniu pierwszego okresu ubezpieczenia iloczynowi udziału procentowego obowiązującego $\mathrm{w}$ dniu poprzedzającym początek miesiąca ochrony, w którym nastąpiło zdarzenie ubezpieczeniowe i sumy ubezpieczenia.

Przez pierwszy okres ubezpieczenia rozumie się okres rozpoczynający się w pierwszym dniu okresu odpowiedzialności, a kończący się w dniu poprzedzającym rocznicę pierwszego dnia okresu odpowiedzialności. Natomiast pierwotny udział procentowy jest ustalany w momencie zawierania umowy ubezpieczenia. Pierwotny udział procentowy oraz udział procentowy jest równy $100 \%$, gdy ochroną ubezpieczeniową objęty jest jeden ubezpieczony lub 50\%, gdy ochorną ubezpieczeniową objętych jest dwóch ubezpieczonych w ramach jednej umowy kredytu.

Bank Pekao oferuje ubezpieczenia na życie obejmujące zgon w następstwie nieszczęśliwego wypadku. Ochroną z tytułu zgonu objęte są wszystkie trzy kategorie ubezpieczonych:

- ubezpieczony zatrudniony na podstawie stosunku pracy zawartego na czas nieokreślony,

- ubezpieczony zatrudniony na podstawie stosunku pracy zawartego na czas określony lub prowadzący działalność gospodarczą lub wykonujący działalność zarobkową w innej formie,

- ubezpieczony niezdolny do pracy lub posiadający prawo do emerytury (niezależnie od osiągania przez niego dochodu) albo nieosiągający dochodu.

${ }^{5} \S 10$. ust. 2 Ogólne warunki ubezpieczenia na życie dla klientów PKO BP i PKO Banku Hipotecznego SA, którzy zawarli umowy kredytu lub pożyczki zabezpieczone hipoteką, PKO Życie Towarzystwo Ubezpieczeń SA, UI/OWU/138/04-2017/A, s. 4. 
W przypadku śmierci ubezpieczonego wskutek nieszczęśliwego wypadku ubezpieczyciel wypłaca świadczenie w wysokości:

1) w stosunku do - ubezpieczonych zatrudnionych na podstawie stosunku pracy zawartego na czas nieokreślony oraz ubezpieczonych zatrudnionych na podstawie stosunku pracy zawartego na czas określony lub prowadzący działalność gospodarczą oraz wykonujących działalność zarobkową w innej formie $40 \%$ salda zadłużenia obliczonego na dzień śmierci ubezpieczonego,

2) w stosunku do - ubezpieczonych niezdolnych do pracy lub posiadających prawo do emerytury (niezależnie od osiągania przez niech dochodu) albo nieosiągających dochód - 100\% salda zadłużenia obliczonego na dzień zgonu ubezpieczonego ${ }^{6}$. Oznacza to, że dla dwóch kategorii ubezpieczonych stopień ochrony jest częściowy (40\%), a tylko dla jednej, najmniej licznej, pełny (100\%).

Suma ubezpieczenia w Banku Pekao, stanowi górną granicę odpowiedzialności zakładu ubezpieczeń. Suma ubezpieczenia odpowiada saldu zadłużenia na dzień wystąpienia zdarzenia ubezpieczeniowego objętego ochroną ubezpieczeniową i jest nie wyższa niż kwota kredytu.

Ograniczenia odpowiedzialności o ogólnym charakterze, do kredytów Banku Pekao, są takie same dla ubezpieczenia utraty dochodu z tytułu czasowej niezdolności do pracy, jak i świadczenia w przypadku zgonu w następstwie nieszczęśliwego wypadku? ${ }^{7}$ W tym wypadku wyłączenia ogólne uchylają odpowiedzialność zakładu ubezpieczeń, która jest następstwem, gdy zajście zdarzenia ubezpieczeniowego nastąpiło $\mathrm{w}$ wyniku następstwa ${ }^{8}$ :

- samobójstwa lub usiłowania popełnienia samobójstwa - jeżeli samobójstwo lub usiłowanie samobójstwa nastąpiło w okresie do 2 lat od daty zawarcia umowy ubezpieczenia,

- działania ubezpieczonego w stanie nietrzeźwości, po użyciu alkoholu, po użyciu narkotyków lub innych substancji odurzających,

- aktów wojny (w tym wojny domowej), czynnego uczestnictwa ubezpieczonego w zamieszkach, przestępstwach, aktach terroryzmu lub sabotażu,

- eksplozji atomowej oraz napromieniowania,

- poddania się przez ubezpieczonego zabiegom o charakterze medycznym poza kontrolą lekarską lub uprawnionych do tego osób,

- prowadzenia przez ubezpieczonego pojazdu mechanicznego bez wymaganych uprawnień,

${ }^{6} \S 3$ ust. 7. Ubezpieczenie dla Kredytobiorców Kredytów Mieszkaniowych Banku Pekao SA, Sopockie Towarzystwo Ubezpieczeń Ergo Hestia SA, KH-PEKAO 01/18), s. 6.

${ }^{7} \S 9$ ust. 2. Ubezpieczenie dla Kredytobiorców Kredytów Mieszkaniowych Banku Pekao SA, Sopockie Towarzystwo Ubezpieczeń Ergo Hestia SA, KH-PEKAO 01/18), s. 9-10.

${ }^{8} \S 9$ ust. 2. Ubezpieczenie dla Kredytobiorców Kredytów Mieszkaniowych Banku Pekao SA, Sopockie Towarzystwo Ubezpieczeń Ergo Hestia SA, KH-PEKAO 01/18), s. 9-10. 
- uczestnictwa ubezpieczonego w locie, w charakterze pilota, członka załogi lub pasażera samolotu wojskowego lub prywatnego nieposiadającego licencji na przewóz pasażerów,

- umyślnego samookaleczenia lub uszkodzenia ciała na prośbę ubezpieczonego.

Ubezpieczyciel nie wypłaci świadczenia z tytułu zgonu ubezpieczonego w następstwie nieszczęśliwego wypadku, jeżeli był on spowodowany następstwem:

1) choroby, w tym występującą nagle, tj. zawałem serca, udarem mózgu, krwotokiem śródmózgowym,

2) czynników chorobotwórczych pochodzenia bakteryjnego, wirusowego, grzybiczego (zakażenia) oraz pasożytniczego (zarażenia, choroby inwazyjne - pasożytnicze), przy zastrzeżeniu, że odpowiedzialność ubezpieczyciela istnieje, jeżeli zakażenie ubezpieczonego mikroorganizmem chorobotwórczym nastąpiło w wyniku ran odniesionych wskutek nieszczęśliwego wypadku będącego przyczyną zgonu9 .

Nieszczęśliwy wypadek to ,nagłe zdarzenie wywołane przyczyną zewnętrzną, w wyniku którego ubezpieczony, niezależnie od swojej woli doznał uszkodzenia ciała lub rozstroju zdrowia lub zmarl"10. Ubezpieczyciel nie sprecyzował pojęcia nagłe zdarzenie, nie wskazał również co należy rozumieć poprzez przyczynę zewnętrzną.

Ochrona nie obejmuje zgonu z powodu nagłej choroby, nawet jeżeli ubezpieczony wcześniej się nie leczył lub choroba nie była u niego zdiagnozowana, tylko w wyniku działania siły zewnętrznej (np. wypadku komunikacyjnego). Niepotrzebnie pojawia się połączenie nieszczęśliwego wypadku $\mathrm{z}$ chorobą $\mathrm{w}$ treści tego zapisu, skoro zgon z powodu choroby nigdy nie będzie zgonem z tytułu nieszczęśliwego wypadku. Klauzulę tę cechuje wysoka niepewność interpretacyjna. Uprawniony nie będzie nigdy pewny, jak zdarzenie zostanie ocenione przez ubezpieczyciela, poza ewidentnymi przypadkami.

W przypadku zawarcia jednej umowy kredytu przez kilka osób fizycznych jako kredytobiorców, ubezpieczyciel obejmuje ochroną ubezpieczeniową tylko jednego kredytobiorcę.

Podsumowując przeprowadzone badanie należy stwierdzić, że ochrona kredytobiorców PKO BP jest szersza, aniżeli Banku Pekao. Ubezpieczenia oferowane przez badane banki różniły się zakresem ochrony ubezpieczeniowej. Poza odpowiedzialnością za zgon, która jest podobnie uregulowana w każdym $\mathrm{z}$ badanych o.w.u. w wypadku PKO BP kredytobiorcy mają dodatkową ochronę z tytułu wystąpienia u ubezpieczonego trwałej i całkowitej niezdolności do pracy i samodzielnej egzystencji będącej następstwem nieszczęśliwych wypadków.

${ }^{9} \S 9$ ust. 3. Ubezpieczenie dla Kredytobiorców Kredytów Mieszkaniowych Banku Pekao SA, Sopockie Towarzystwo Ubezpieczeń Ergo Hestia SA, KH-PEKAO 01/18), s. 10.

${ }^{10} \S 1$ ust. 3 pkt 13. Ubezpieczenie dla Kredytobiorców Kredytów Mieszkaniowych Banku Pekao SA, Sopockie Towarzystwo Ubezpieczeń Ergo Hestia SA, KH-PEKAO 01/18), s. 3. 
Tabela 1. Badane kategorie o.w.u. Banku PKO BP i Banku Pekao SA

\begin{tabular}{|c|c|}
\hline PKO BP & Bank Pekao SA \\
\hline \multicolumn{2}{|c|}{ Ubezpieczyciel ws pólpracujący z bankiem } \\
\hline PKO Życie Towarzystwo Ubezpieczeń SA & Sopockie Towarzystwo Ubezpieczeń ERGO Hestia SA \\
\hline \multicolumn{2}{|c|}{ Przedmiot ubezpieczenia } \\
\hline życie i zdrowie & życie \\
\hline \multicolumn{2}{|c|}{ Zakres ubezpieczenia } \\
\hline $\begin{array}{l}\text { 1) zgon ubezpieczonego i } \\
\text { 2) wystąpienie u ubezpieczonego trwałej i całkowitej niezdolności do } \\
\text { pracy i samodzielnej egzystencji będącej następstwem } \\
\text { nieszczęśliwego wypadku }\end{array}$ & 1) zgon w następstwie nieszczęśliwego wypadku \\
\hline \multicolumn{2}{|c|}{ Definicje zdarzeń objętych odpowie dzialnością zakladu ubezpieczeń } \\
\hline $\begin{array}{l}\text { 1) Nieszczę́liwy wypadek to ,zdarzenie nagle, wywołane działającą } \\
\text { nagle i niezależnie od woli oraz stanu zdrowia Ubezpieczonego, } \\
\text { przyczyną zewnętrzną z wylączeniem działania czynników } \\
\text { biologicznych (drobnoustrojów chorobotwórczych i pasożytów), } \\
\text { będące bezpośrednią i wylączną przyczyną wystąpienia zdarzenia } \\
\text { objętego zakresem ubezpieczenia” } \\
\text { 2) Trwała i całkowita niezdolność do pracy i samodzielnej egzystencji } \\
\text { rozumiana jest jako „trwała i całkowita niezdolność do pracy i } \\
\text { samodzielnej egzystencji orzeczona przez uprawniony organ do } \\
\text { orzekania w sprawie oceny zdolności do pracy (...) niezdolność do } \\
\text { samodzielnej egzystencji oznacza naruszenie sprawności organizmu w } \\
\text { stopniu, który powoduje konieczność stałej lub długotrwałej opieki i } \\
\text { pomocy innej osoby w celu zaspokajania podstawowych potrzeb } \\
\text { życiowych” }\end{array}$ & $\begin{array}{l}\text { 1) Nieszczęśliwy wypadek to „nagłe zdarzenie wywołane przyczyną } \\
\text { ze-wnętrzną, w wyniku którego ubezpieczony, niezależnie od swojej } \\
\text { woli doznał uszkodzenia ciała lub rozstroju zdrowia lub zmarł’ }\end{array}$ \\
\hline \multicolumn{2}{|c|}{ Charakter świadczenia } \\
\hline $\begin{array}{l}\text { Poziom świadczeń jest identyczny w przypadku zajścia każdego ze } \\
\text { zdarzeń: } \\
100 \% \text { sumy ubezpieczenia w przypadku jednego kredytobiorcy } \\
50 \% \text { sumy ubezpieczenia w przypadku dwóch kredytobiorców }\end{array}$ & $\begin{array}{l}40 \% \text { salda zadłużenia dla ubezpieczonych zatrudnionych na } \\
\text { podstawie stosunku pracy zawartego na czas nieokreślony oraz } \\
\text { ubezpieczonych zatrudnionych na podstawie stosunku pracy } \\
\text { zawartego na czas określony lub prowadzący działalność } \\
\text { gospodarczą oraz wykonujących działalność zarobkową w innej } \\
\text { formie } \\
100 \% \text { salda zadłużenia dla ubezpieczonych niezdolnych do pracy lub } \\
\text { posiadających prawo do emerytury (niezależnie od osiągania przez } \\
\text { niech dochodu) albo nieosiągających dochód }\end{array}$ \\
\hline \multicolumn{2}{|c|}{ Wylączenia i ograniczenia - ilość } \\
\hline 9 & 10 \\
\hline \multicolumn{2}{|c|}{ Suma ubezpieczenia } \\
\hline $\begin{array}{l}\text { W pierwszym okresie ubezpieczenia: } \\
\text { - jeżeli kredytobiorca zawarł umowę ubezpieczenia nie później niż w } \\
\text { dniu wypłaty całkowitej kwoty kredytu jest równa kwocie } \\
\text { udzielonego kredytu } \\
\text { - jeżeli do zawarcia umowy ubezpieczenia doszło po dniu wypłaty } \\
\text { całkowitej kwoty kredytu jest równa saldu zadłużenia na dzień } \\
\text { zawarcia umowy ubezpieczenia. } \\
\text { Po pierwszym okresie ubezpieczenia: } \\
\text { - jest równa saldu zadłużenia z dnia poprzedzającego początek } \\
\text { miesiąca ochrony, w którym nastąpiło zdarzenie ubezpieczeniowe }\end{array}$ & $\begin{array}{l}\text { Odpowiada saldu zadłużenia na dzień wystąpienia zdarzenia } \\
\text { ubezpieczeniowego, nie wyższa niż kwota kredytu }\end{array}$ \\
\hline \multicolumn{2}{|c|}{ Liczba potencjalnych kredytobiorców } \\
\hline $\begin{array}{l}\text { Ochroną ubezpieczeniową może być objętych maksymalnie dwóch } \\
\text { kredytobiorców }\end{array}$ & $\begin{array}{l}\text { Ochroną ubezpieczeniową może być objęty tylko jeden } \\
\text { kredytobiorca }\end{array}$ \\
\hline
\end{tabular}

Źródło: opracowanie własne na podstawie zapisów ogólnych warunków ubezpieczenia dla Kredytobiorców Kredytów Mieszkaniowych Banku Pekao SA, Sopockie Towarzystwo Ubezpieczeń Ergo Hestia SA, KH-PEKAO 01/18); PKO BP i PKO Banku Hipotecznego SA, którzy zawarli umowy kredytu lub pożyczki zabezpieczone hipoteką, PKO Życie Towarzystwo Ubezpieczeń SA, UI/OWU/138/04-2017/A. 
Pojęcie nieszczęśliwego wypadku zostało w obu o.w.u. uregulowane podobnie. W obydwu przypadkach zakład ubezpieczeń nie sprecyzował pojęć, takich jak: „nagłe zdarzenie” oraz „przyczyna zewnętrzna”. Na niekorzyść o.w.u. dodawanych do kredytów świadczy lista wyłączeń odpowiedzialności, obejmująca zdarzenia z tytułu uprawiania niektórych sportów czy rodzajów aktywności.

Wysokość świadczeń z tytułu zdarzeń objętych ubezpieczeniem dla klientów PKO BP jest wyższa. Odpowiedzialność ubezpieczyciela w przypadku jednego kredytobiorcy pokrywa się z wysokością kredytu lub saldem zadłużenia. W przypadku Banku Pekao wysokość świadczeń tylko dla najwęższej grupy ubezpieczonych wynosi $100 \%$, natomiast dla pozostałych tylko $40 \%$ salda zadłużenia. W ubezpieczeniu oferowanym prze PKO BP do ubezpieczenia może przystąpić maksymalnie dwóch kredytobiorców - w przypadku Banku Pekao tylko jeden. Informacje zawarte w o.w. u. ubezpieczeń na życie dodawanych do kredytów mieszkaniowych zostały przedstawione w tabeli 1 .

\section{PODSUMOWANIE}

Umowa ubezpieczenia to kontrakt najwyższego zaufania, ponieważ prawidłowość realizacji ochrony ubezpieczeniowej opiera się na wzajemnej lojalności stron umowy. Ubezpieczyciel oraz ubezpieczający nie powinni ukrywać istotnych informacji i wykorzystywać braku świadomości i wiedzy drugiej strony kontraktu. Celem umowy ubezpieczenia jest zapewnienie ochrony ubezpieczonemu podmiotowi. Pewność ochrony jest fundamentem ubezpieczeń. Każdy przypadek odmowy wypłaty świadczenia podważa zaufanie konsumentów do zakładów ubezpieczeń (P. Nowak, 2019: 57-67).

Konsument-kredytobiorca musi być ostrożny przy wyborze ubezpieczenia. Tylko na podstawie analizy treści warunków ubezpieczenia może wybrać ubezpieczenie dopasowane do jego potrzeb.

Badania własne ukazały problem czytelności o.w.u. Po zapoznaniu się z treścią o.w.u. kredytobiorca-konsument może nie mieć pewności, czy uzyska pomoc, gdy będzie jej potrzebował. Oznacza to, że wciąż ważne jest doprecyzowanie pojęć, którymi posługują się ubezpieczyciele. Pomimo dotychczasowych wysiłków regulatora, polegających m.in. na poprawie czytelności dokumentów, wzorce umowne są wciąż skomplikowane i nieczytelne dla konsumentów. Konsument może mieć problem z porównaniem ofert i wybraniem ubezpieczenia użytecznego, czyli dopasowanego do jego indywidualnych potrzeb.

Zakłady ubezpieczeń mogą dowolnie kształtować treść umowy ubezpieczenia. Prawo wymaga jednak, aby postanowienia były formułowane w sposób jednoznaczny i zrozumiały (art. 15 ust. 3 u.d.u.r.). Doprecyzowanie aparatu pojęciowego jest potrzebne $\mathrm{w}$ celu wyeliminowania rozbieżności interpretacyjnych 
w procesie likwidacji szkody. Konsument musi w sposób jednakowy odbierać treść i sens poszczególnych przepisów, aby wybrać adekwatne do potrzeb ubezpieczenie.

Przeprowadzona w badaniu analiza o.w.u. pozwoliła na ustalenie potencjalnych ram ochrony ubezpieczeniowej. W celu ustalenia rzeczywistego poziomu ochrony konieczne byłoby skonfrontowanie wniosków z przeprowadzonej analizy z doświadczeniami konsumentów, wyrażonymi w skargach składanych do Rzecznika Finansowego.

\section{BIBLIOGRAFIA}

Barczuk-Grędzińska, K. (2018). Czytelność ogólnych warunków ubezpieczenia - teoria i zastosowanie w praktyce [rozprawa doktorska]. Wrocław: Uniwersytet Ekonomiczny we Wrocławiu.

Barczuk-Grędzińska, K. (2019). Badanie stopnia przystępności tekstów wybranych ogólnych warunków ubezpieczenia na polskim rynku. Oblicza komunikacji, 11.

Barembruch, A. (2019). Zarzadzanie finansami osobistymi. Teoria i praktyka. Gdańsk: Wydawnictwo Uniwersytetu Gdańskiego.

Dąbrowska, E. (2018). Ubezpieczenia zdrowotne. W: M. Iwanicz-Drozdowska, red., Ubezpieczenia. Warszawa: PWE.

Dorfman, M.S. (2013). Introduction to risk management and insurance. New Jersey: Prentice Hall.

Gawin, M. (2018). Różnice definicyjne w ogólnych warunkach ubezpieczeń jako czynnik ograniczający odpowiedzialność towarzystwa ubezpieczeniowego na wybranych przykładach. Rozprawy Ubezpieczeniowe, 1(27).

Heropolitańska, I. (2018). Prawne zabezpieczenia zapłaty wierzytelności. Warszawa: Wolters Kluwer.

Iwko, J. (2014). Model oceny jakości uslug ubezpieczeniowych na polskim rynku [rozprawa doktorska]. Wrocław: Uniwersytet Ekonomiczny we Wrocławiu.

Kawiński, M. (2017). Finanse osobiste. Planowanie ochrony ubezpieczeniowej. Warszawa: Oficyna Wydawnicza SGH.

Mrozowska, B. i Wnęk, A. (2014). Umowa ubezpieczenia na życie jako zabezpieczenie kredytu hipotecznego. Prawo Asekuracyjne, 4(81).

Nowak, K. (2020). Dystrybucja ubezpieczeń o charakterze ochronnym w kanale bankowym w kontekście zmian regulacyjnych. W: M. Jagielska, E. Sługocka-Krupa, K. Podgórski, red., Dochodzenie roszczeń konsumenckich. Nowy ład dla konsumenta. Warszawa: C.H.Beck.

Nowak, P. (2018). Wpływ zmian systemowych i prawnych na poprawę adekwatności produktów ubezpieczeniowych do potrzeb i wymagań klientów. Prace Komisji Geografii Przemystu Polskiego Towarzystwa Geograficznego, 32(2).

Nowak, P. (2019). Ubezpieczenie kredytu gotówkowego - korzyści dla kredytobiorcy czy kredytodawcy. W: B. Gnela, E. Sługocka-Krupa, M. Szaraniec, A. Viglianisi Ferraro, red., Prawo konsumenckie w Polsce oraz innych wybranych państwach UE. Zagadnienia wybrane. Warszawa: C.H.Beck.

Nowak, P. (2020). Sprzedaż krzyżowa kredytów mieszkaniowych i ubezpieczeń a wybór konsumenta. W: A. Gemzik-Salwach, K. Opolski, red., Gospodarka i społeczeństwo w dobie finansjalizacji. Warszawa: CeDeWu.

Ogólne warunki ubezpieczenia na życie dla klientów PKO BP i PKO Banku Hipotecznego SA, którzy zawarli umowy kredytu lub pożyczki zabezpieczone hipoteką, PKO Życie Towarzystwo Ubezpieczeń SA, UI/OWU/138/04-2017/A. 
Orlicki, M. (2013). Ubezpieczenie na życie jako instrument zabezpieczenia wierzytelności banku. W: K. Szuma, red., Ochrona interesów wierzycieli w stosunkach gospodarczych. Poznań: Wydawnictwo Uniwersytetu Ekonomicznego w Poznaniu.

Ranking przyjazny bank „Newsweeka” (2019). Newsweek, 40.

Raport Amron-Sarfin. Ogólnopolski raport o kredytach mieszkaniowych i cenach transakcyjnych nieruchomości 4/2020 (2021). Centrum Amron i Związek Banków Polskich, 46.

Rejda, G.E. and McNamara, M.J. (2018). Principles of Risk Management and Insurance. Boston: Pearson.

Rekomendacja U dotyczaca dobrych praktyk w zakresie bancassurance (2014). Urząd Komisji Nadzoru Finansowego, Warszawa [dostęp 05.02.2021].

Sprawozdanie z działalności Rzecznika Finansowego w 2020 r. oraz uwagi o stanie przestrzegania prawa $i$ interesów klientów podmiotów rynku finansowego $i$ sprawozdanie $z$ działalności w 2020 r. finansowanej ze środków funduszu edukacji finansowej wraz z informacja o wykorzystaniu środków funduszu (2021). Rzecznik Finansowy, Warszawa.

Stęplewska, K. (2016). Analiza pozostałych ubezpieczeń osobowych i majątkowych. W: D. Ostrowska, P. Jamróz, red., Ubezpieczenia gospodarcze i społeczne w Polsce. Warszawa: CeDeWu.pl.

Szydłowska, N. (2018). Bank jako uprawniony do dochodzenia roszczeń z umowy ubezpieczenia zawartej jako zabezpieczenie spłaty kredytu. Wiadomości Ubezpieczeniowe, 3.

Śliwiński, A. (2016). Ubezpieczenia na życie. W: W. Ronka-Chmielowiec, red., Ubezpieczenia. Warszawa: C.H.Beck.

Ubezpieczenie dla Kredytobiorców Kredytów Mieszkaniowych Banku Pekao SA, Sopockie Towarzystwo Ubezpieczeń Ergo Hestia SA, KH-PEKAO 01/18.

Ustawa z dnia 11 września 2015 r. o działalności ubezpieczeniowej i reasekuracyjnej, t.j. Dz.U. 2020, poz. 895 ze zm.

Ustawa z dnia 15 grudnia 2017 r., o dystrybucji ubezpieczeń, t.j. Dz.U. 2019, poz. 1881, ze zm.

Ustawa z dnia 23 kwietnia 1964 r. - Kodeks cywilny, t.j. Dz.U. 2020, poz. 1740 ze zm.

Ustawa z dnia 23 marca 2017 r. o kredycie hipotecznym oraz o nadzorze nad pośrednikami kredytu hipotecznego i agentami, t.j. Dz.U. 2020, poz. 1027 ze zm.

Więcko-Tułowiecka, M. (2015). Ubezpieczenia grupowe z perspektywy konsumenta. W: J. Monkiewicz, M. Orlicki, red., Ochrona konsumentów na rynku ubezpieczeniowym. Warszawa: PWN.

XXIV Ranking Banków (2019). Bank, 6. 